\title{
Pengembangan Media Pembelajaran Modul Interaktif Dengan Software Adobe Flash pada Mata Kuliah Matematika Ekonomi di Universitas Batanghari Jambi
}

\author{
Diliza Afrila ${ }^{1}$, Ayu Yarmayani ${ }^{2}$ \\ FKIP Universitas Batanghari Jambi, Program Studi Matematika ${ }^{1,2}$
}

\begin{abstract}
This reserach is aimed at identifying (1) the development process of interactive module learning media with Adobe Flash software in Economics Mathematics in Batanghari University Jambi, (2) The advisability of interactive module learning media Adobe Flash software in Economics Mathematics in Batanghari University based on material and media experts assessment, and (3) The advisability of interactive module learning media with Adobe Flash software in Economics Mathematics course in Batanghari University based on students assessment. This research uses Research and Development method. The subject of the research is one expert in Economics Mathematics course, one expert in media, and the students of Economics Education Study Program Faculty of Teachers Training and Education Batanghari University Jambi which cosist of 20 (twenty) people. Moreover, the object of this researh is the advisability of interactive module learning media which consists of 4 aspects, they are; content material, learning material, performance and presentation, and programming. The result of the research shows that (1) The development process of interactive module learning media with Adobe Flash software in Economics Mathematics in Batanghari University Jambi refers to the development model ADDIE which consists of 5 (five) steps, they are; Analysis, Design, Development, Implementation, and Evaluation, (2) The advisability of interactive module learning media with Adobe Flash software in Economics Mathematics Batanghari University Jambi based on Economics Mathematics course based on expert assessment falls into mean category 4,94. It prooves that this learning material can be efficiently used in Economics Mathematics learning process. Furthemore, based on media expert, the process falls into mean category 4,85. It means that this learning media can be efficiently used in Economics Mathematics learning process, and (3) The advisability of interactive module learning media with Adobe Flash software based on learning assessment in Economics Mathematics learning falls into mean category 4,25. It proves that this learning media can be efficiently used in Economics Mathematics learning process.
\end{abstract}

Keywords: Learning Media, Interactive Module, Adobe Flash Software

\section{PENDAHULUAN}

Sumber Daya Manusia (SDM) yang berkualitas, memiliki kompetensi, dan daya saing memegang peranan yang sangat penting dalam menghadapi persaingan yang semakin ketat, terutama pada era Masyarakat Ekonomi ASEAN (MEA) saat ini. Dimana, negara Indonesia harus mampu bersaing dengan negaranegara ASEAN lainnya dalam menghadapi perdagangan bebas. Salah satu upaya yang dapat dilakukan oleh pemerintah Indonesia agar siap menghadapi persaingan di era MEA adalah meningkatkan kualitas SDM secara berkelanjutan. Oleh karena itu, pendidikan mempunyai peranan yang sangat strategis dalam membentuk SDM yang berkualitas dan berdaya saing.

Pendidikan merupakan investasi SDM jangka panjang yang mempunyai nilai strategis bagi kelangsungan kehidupan manusia. Pendidikan bukan hanya merupakan pilar terpenting dalam upaya mencerdaskan kehidupan bangsa, tetapi juga merupakan syarat mutlak bagi peningkatan kesejahteraan masyarakat yang berkeadilan. Hal ini tercantum dalam UUD 1945 Pasal 28C ayat (1) yang menyatakan bahwa "Setiap orang berhak mengembangkan diri melalui pemenuhan kebutuhan dasarnya, berhak mendapatkan pendidikan dan manfaat dari ilmu pengetahuan dan teknologi, seni dan budaya demi meningkatkan kualitas hidupnya demi kesejahteraan umat manusia".

Pendidikan pada hakekatnya dapat ditempuh melalui 3 (tiga) jalur, yaitu pendidikan formal, pendidikan nonformal, dan pendidikan informal. Pendidikan formal adalah jalur pendidikan yang terdiri dari jenjang pendidikan dasar (SD/MI/SMP/MTs), pendidikan menengah (SMA/SMK/MA/MAK), dan pendidikan tinggi (Akademi/Politeknik/Sekolah

Tinggi/Institut/Universitas). Pendidikan 
nonformal adalah jalur pendidikan di luar pendidikan formal (lembaga kursus, lembaga pelatihan, kelompok belajar, pusat kegiatan belajar masyarakat, dan sebagainya). Dan, pendidikan informal adalah pendidikan di dalam keluarga dan lingkungan.

Universitas Batanghari merupakan salah satu bentuk pendidikan formal jenjang pendidikan tinggi yang berada di Provinsi Jambi. Keberhasilan pendidikan di Universitas Batanghari salah satunya ditentukan oleh kualitas dosen. Hal ini dikarenakan, dosen merupakan salah satu unsur manusiawi dalam pendidikan, yang memegang peranan sangat penting dalam proses pembelajaran di Perguruan Tinggi. Oleh karena itu, seorang dosen harus memiliki kompetensi, baik pedagogik, profesional, kepribadian, dan sosial dalam melaksanakan Tri Dharma Perguruan Tinggi, salah satunya berkaitan dengan kegiatan pendidikan dan pengajaran.

Pelaksanaan pembelajaran di Perguruan Tinggi menuntut dosen untuk mampu menciptakan proses pembelajaran yang aktif, inovatif, kreatif, dan menyenangkan. Hal ini dikarenakan, berkualitas atau tidaknya proses pembelajaran sangat bergantung pada kreativitas dan inovasi yang dimiliki oleh dosen dalam mendesain pembelajaran. Oleh karena itu, dosen yang profesional harus lebih mengutamakan kualitas pembelajaran daripada materiil oriented.

Matematika Ekonomi merupakan salah satu mata kuliah yang harus di kontrak oleh mahasiswa Program Studi Pendidikan Ekonomi dan Program Studi Pendidikan Matematika (Fakultas Keguruan dan Ilmu Pendidikan) serta Program Studi Manajemen (Fakultas Ekonomi) Universitas Batanghari Jambi. Mata kuliah Matematika Ekonomi merupakan salah satu mata kuliah yang bekerja dengan angka-angka, sehingga mahasiswa harus mampu terlibat dalam permainan angka-angka tersebut. Sebagian besar mahasiswa beranggapan bahwa mata kuliah Matematika Ekonomi sukar dipelajari, karena mereka tidak familiar dengan angka-angka.

Berdasarkan wawancara peneliti dengan dosen pengampu mata kuliah Matematika Ekonomi di Program Studi Pendidikan Ekonomi diketahui bahwa masih ada mahasiswa yang memperoleh hasil belajar yang rendah. Hal ini tergambar dari nilai murni Ujian Akhir Semester (UAS) yang diperoleh mahasiswa. Dimana, dari 25 (dua puluh lima) orang mahasiswa hanya terdapat 11 (sebelas) orang yang tuntas atau sekitar $44 \%$. Berdasarkan wawancara peneliti dengan beberapa orang mahasiswa Program Studi Pendidikan Ekonomi diperoleh informasi bahwa salah satu faktor penyebab nilai UAS yang kurang maksimal adalah media pembelajaran yang digunakan oleh dosen pengampu mata kuliah Matematika Ekonomi cenderung monoton, sehingga mahasiswa mudah bosan dan kurang berminat mengikuti proses pembelajaran. Selain itu, mahasiswa juga jarang mengulang kembali materi perkuliahan Matematika Ekonomi di rumah, sehingga pada saat UAS mereka lupa cara perhitungan yang telah dipelajari.

Meminimalisir permasalahan yang dialami oleh mahasiswa tersebut, maka salah satu upaya yang peneliti lakukan adalah mendesain media pembelajaran. Menurut Hamdani (2011: 244) "Media pembelajaran adalah segala sesuatu yang dapat menyalurkan pesan, merangsang pikiran, perasaan, dan kemauan siswa, sehingga mendorong terciptanya proses belajar pada diri siswa". Dengan kata lain, penggunaan media pembelajaran dapat meningkatkan motivasi dan minat peserta didik, sehingga terwujud proses pembelajaran yang lebih efektif.

Media pembelajaran yang peneliti kembangkan adalah media pembelajaran yang selaras dengan perkembangan Ilmu Pengetahuan dan Teknologi (IPTEK). Hal ini dikarenakan, pengembangan media pembelajaran dengan memanfaatkan teknologi dapat meningkatkan kualitas pembelajaran. Hal ini senada dengan pendapat Sadiman (2011: 17) yang mengemukakan bahwa "Penggunaan media pendidikan secara tepat dan bervariasi dapat mengatasi sikap pasif peserta didik. Dalam hal ini, media pendidikan salah satunya berguna untuk menimbulkan kegairahan belajar".

Seiring perkembangan IPTEK yang semakin pesat, maka media pembelajaran semakin luas dan interaktif. Selain itu, softwaresoftware yang dapat dikembangkan dalam proses pembelajaran semakin banyak, salah satunya Adobe Flash. Adobe Flash mempunyai tampilan utama yang memuat teks, gambar, suara, animasi, video, dan film sesuai dengan kebutuhan dilengkapi dengan tombol-tombol interaktif, sehingga proses pembelajaran menjadi lebih bermakna dan mampu meningkatkan hasil belajar mahasiswa. Oleh karena itu, peneliti sangat tertarik untuk mengembangkan media pembelajaran modul interaktif dengan software Adobe Flash pada mata kuliah Matematika Ekonomi di Program Studi Pendidikan Ekonomi dan Program Studi Pendidikan Matematika 
(Fakultas Keguruan dan Ilmu Pendidikan) serta Program Studi Manajemen (Fakultas Ekonomi) Universitas Batanghari Jambi Tahun Ajaran 2017/2018, karena dapat diakses secara mandiri dan berulang-ulang oleh mahasiswa, dimana saja dan kapan saja.

Adapun tujuan penelitian ini adalah untuk mengetahui (1) Proses pengembangan media pembelajaran modul interaktif dengan software Adobe Flash pada mata kuliah Matematika Ekonomi di Universitas Batanghari Jambi, (2) Kelayakan media pembelajaran modul interaktif dengan software Adobe Flash pada mata kuliah Matematika Ekonomi di Universitas Batanghari Jambi berdasarkan penilaian ahli materi dan ahli media, dan (3) Kelayakan media pembelajaran modul interaktif dengan software Adobe Flash pada mata kuliah Matematika Ekonomi di Universitas Batanghari Jambi berdasarkan penilaian mahasiswa.

\section{METODE PENELITIAN}

Penelitian yang dilaksanakan ini termasuk metode penelitian dan pengembangan (Research and Development). Menurut Sugiyono (2011: 297) "Metode penelitian dan pengembangan atau dalam bahasa Inggrisnya Research and Development adalah metode penelitian yang digunakan untuk menghasilkan produk tertentu, dan menguji keefektifan produk tersebut". Penelitian ini bertujuan untuk mengembangkan media pembelajaran Matematika Ekonomi berupa modul interaktif dengan software Adobe Flash.

Subjek penelitian adalah satu orang ahli materi, satu orang ahli media, dan mahasiswa Program Studi Pendidikan Ekonomi Fakultas Keguruan dan Ilmu Pendidikan Universitas Batanghari Jambi yang berjumlah 20 (dua puluh) orang. Sedangkan, objek penelitian adalah kelayakan media pembelajaran modul interaktif, yang meliputi aspek materi, aspek pembelajaran, aspek tampilan dan penyajian media, serta aspek pemprograman.

Prosedur penelitian yang digunakan mengadaptasi model pengembangan ADDIE. Gafur (2012: 38) mengemukakan bahwa model ADDIE terdiri dari 5 (lima) komponen atau langkah, yaitu (1) Analisis (Analysis), (2) Desain (Design), (3) Pengembangan (Develop), (4) Implementasi (Implement), dan (5) Evaluasi (Evaluate). Instrumen pengumpulan data yang digunakan adalah angket. Sugiyono (2011: 142) mengemukakan bahwa "Kuesioner adalah teknik pengumpulan data yang dilakukan dengan cara memberi seperangkat pertanyaan atau pernyataan tertulis kepada responden untuk dijawabnya". Angket penelitian ini bertujuan untuk mengukur kelayakan media, baik oleh ahli materi, ahli media, dan mahasiswa sebagai bahan untuk mengevaluasi produk/media pembelajaran yang dikembangkan.

Data yang diperoleh dianalisis guna mengetahui penilaian tentang produk yang dihasilkan. Data proses pengembangan produk merupakan data deskriptif yang diperoleh dari ahli materi, ahli media, dan mahasiswa. Sedangkan, Data penilaian kelayakan produk diperoleh dari angket yang diisi oleh ahli materi, ahli media, dan mahasiswa. Data tersebut selanjutnya dianalisis dengan mengikuti langkah-langkah sebagai berikut (1) Mengubah penilaian kualitatif menjadi kuantitatif, (2) Menghitung skor rata-rata, dan (3) Menginterpretasikan secara kualitatif nilai ratarata setiap aspek dan seluruh aspek.

\section{HASIL PENELITIAN}

\section{Proses Pengembangan Media Pembelajaran Modul Interaktif dengan Software Adobe Flash pada Mata Kuliah Matematika Ekonomi di Universitas Batanghari Jambi}

Prosedur yang peneliti gunakan dalam pengembangan media pembelajaran modul interaktif dengan Software Adobe Flash merujuk pada model pengembangan ADDIE. Adapun langkah-langkah model pengembangan ADDIE adalah sebagai berikut:

\section{Analisis (Analysis)}

Analisis dilakukan untuk menentukan kebutuhan belajar, apa yang akan diajarkan, dan kompetensi apa yang diharapkan dikuasai mahasiswa setelah belajar. Uraian dari masingmasing tahap analisis ini adalah sebagai berikut:

a. Analisis kebutuhan

Analisis kebutuhan peneliti peroleh melalui kegiatan observasi. Berdasarkan observasi yang peneliti lakukan diperoleh informasi bahwa dosen pengampu mata kuliah Matematika Ekonomi dalam proses pembelajaran hanya menggunakan metode ceramah dengan memanfaatkan papan tulis sebagai media pembelajaran. Dengan kata lain, dosen pengampu mata kuliah Matematika Ekonomi belum menggunakan media pembelajaran yang inovatif, terutama yang berbasis komputer. Padahal, disetiap ruangan kelas telah tersedia $\mathrm{LCD}$, yang bisa dimanfaatkan selama proses pembelajaran. 
Selain itu, sebagian besar mahasiswa juga memiliki laptop yang bisa digunakan secara efektif untuk menunjang proses pembelajaran. Dengan demikian, pengembangan modul interaktif dengan software Adobe Flash diharapkan dapat meningkatkan kualitas pembelajaran dan kemandirian belajar mahasiswa pada mata kuliah Matematika Ekonomi.

b. Analisis materi

Analisis materi diperoleh melalui kegiatan diskusi yang peneliti laksanakan dengan dosen pengampu mata kuliah Matematika Ekonomi. Peneliti melaksanakan diskusi sebanyak 3 (tiga) kali. Pertama, pelaksanaan diskusi dengan dosen pengampu mata kuliah Matematika Ekonomi di Program Studi Pendidikan Ekonomi (Pratiwi Indah Sari, M.PdE) dan Program Studi Matematika (Ayu Yarmayani, M.Pd) pada tanggal 19 Februari 2018. Kedua, pelaksanaan diskusi dengan dosen pengampu mata kuliah Matematika Ekonomi di Program Studi Manajemen (Anisah, SE, MM) pada tanggal 22 Februari 2018. Pelaksanaan-pelaksanaan diskusi di atas membahas tentang materi yang disajikan pada mata kuliah Matematika Ekonomi di masing-masing Program Studi. Ketiga, pelaksanaan diskusi dengan anggota peneliti pada tanggal 26 Februari 2018. Pelaksanaan diskusi ini membahas tentang materi yang akan dijabarkan ke dalam modul interaktif dengan software Adobe Flash. Dengan mempertimbangkan hasil diskusi sebelumnya, maka diperoleh keputusan bahwa materi yang akan dijabarkan ke dalam modul interaktif dengan software Adobe Flash adalah Deret dan Fungsi Linier.

c. Analisis kompetensi

Setelah materi yang akan dijabarkan ke dalam modul interaktif dengan software Adobe Flash ditentukan, maka peneliti merumuskan kompetensi penunjang materi deret dan fungsi linier. Adapun kompetensi penunjang materi deret adalah sebagai berikut:

1) Memahami konsep suku ke-n dan jumlah $\mathrm{n}$ suku dari deret hitung.

2) Memahami konsep suku ke-n dan jumlah n suku dari deret ukur.

3) Mengaplikasikan konsep deret hitung pada model perkembangan usaha.

4) Mengaplikasikan konsep deret ukur pada model bunga majemuk.
5) Mengaplikasikan konsep deret ukur pada model pertumbuhan penduduk.

Sedangkan, kompetensi penunjang

materi fungsi linier adalah sebagai berikut:

1) Memahami konsep fungsi.

2) Memahami konsep fungsi linier.

3) Memahami sistem persamaan linier.

4) Memahami fungsi permintaan.

5) Memahami fungsi penawaran.

6) Memahami keseimbangan pasar satu macam produk.

7) Memahami keseimbangan pasar dua macam produk.

8) Memahami pengaruh pajak terhadap kesejahteraan.

9) Memahami pengaruh subsidi terhadap kesejahteraan.

10) Memahami fungsi konsumsi dan tabungan.

11) Memahami fungsi investasi.

\section{Desain (Design)}

Setelah kebutuhan belajar diidentifikasi, langkah berikutnya adalah sebagai berikut:

a. Pembuatan storyboard

Storyboard menggambarkan secara keseluruhan hubungan antara bagian dalam media pembelajaran. Pendesainan storyboard ini bertujuan untuk memudahkan proses pembuatan media pembelajaran.

b. Pengumpulan objek rancangan

Langkah-langkah dalam pengumpulan objek rancangan adalah sebagai berikut:

1) Penyusunan materi pembelajaran, latihan beserta jawaban.

Materi pembelajaran disusun secara runtut berdasarkan referensi yang telah ditentukan sebelumnya. Dimana, referensi yang peneliti gunakan adalah buku Matematika Ekonomi karangan Dumairy dan JB. Kalangi. Materi pembelajaran ini terlebih dahulu peneliti susun dalam format Microsoft Word, yang selanjutnya peneliti copy ke dalam software Adobe Flash CS 6 dengan format flash document (.fla).

Selanjutnya, soal latihan masingmasing materi, baik deret maupun fungsi linier juga terlebih dahulu peneliti susun dalam format Microsoft Word, yang selanjutnya peneliti copy ke dalam software Adobe Flash CS 6 dengan format flash document (.fla). Latihan masingmasing materi terdiri dari 5 (lima) soal berbentuk pilihan ganda. Setelah latihan 
beserta jawabannya disusun, maka langkah selanjutnya adalah peneliti mengatur penskoran latihan untuk masingmasing materi. Dimana, jawaban benar mendapatkan skor 20 (dua puluh) dan salah mendapatkan skor 0 (nol).

2) Pembuatan button atau tombol

Button atau tombol didesain oleh peneliti dengan dibantu oleh 2 (dua) orang mahasiswa.

3) Pengambilan gambar, background, dan musik.

Gambar yang disajikan pada modul interaktif peneliti unduh atau download dari berbagai sumber, yang kemudian peneliti import ke dalam software Adobe Flash. Sedangkan, background dibuat berdasarkan kombinasi dari gambar yang telah peneliti unduh atau download. Selanjutnya, musik yang peneliti gunakan pada modul interaktif adalah musik instrumental. Penggunaan musik instrumental bertujuan agar proses pembelajaran Matematika Ekonomi lebih menarik bagi mahasiswa.

c. Penyusunan instrumen penilaian

Instrumen penilaian yang peneliti susun terdiri atas 3 (tiga), yaitu instrumen penilaian tentang kelayakan materi oleh ahli materi, instrumen penilaian tentang kelayakan media oleh ahli media, dan instrumen penilaian tentang kelayakan materi dan media oleh mahasiswa. Instrumen-instrumen penilaian tersebut peneliti susun dalam bentuk angket dengan 5 (lima) alternatif jawaban, yaitu Sangat Baik, Baik, Cukup, Tidak Baik, dan Sangat Tidak Baik.

\section{Pengembangan (Develop)}

a. Pembuatan media pembelajaran

Berdasarkan desain yang sudah dirancang, maka peneliti membuat media pembelajaran modul interaktif. Media pembelajaran modul interaktif ini dibuat menggunakan software Adobe Flash CS 6. Seluruh komponen yang telah disusun pada tahap desain dirangkai menjadi satu kesatuan yang utuh. Dimana, materi pembelajaran, latihan beserta jawabannya, button atau tombol, gambar, background, dan musik yang digunakan pada media pembelajaran di import ke dalam software Adobe Flash CS 6. Berkas-berkas yang dibuat menggunakan software ini berbentuk flash document (.fla) dan dapat dioperasikan di luar area kerja Adobe Flash setelah dipublish ke dalam flash movie (.swf). Pembuatan modul interaktif ini terdiri atas 4 (empat) tahap, yaitu:

1) Pembuatan antar berkas

Pembuatan antar berkas menggunakan software Adobe flash CS 6. Pembuatan antar berkas ini sesuai dengan storyboard yang telah peneliti rancang. Setiap berkas berisi tampilan menu dengan bentuk flash document (.fla).

2) Penggabungan

Tahap penggabungan dilakukan dengan cara mengcopy seluruh file flash document (.fla) menjadi satu. Setelah file menjadi satu, maka dalam actionscript diberi rumus agar file dapat dibuka menjadi satu kesatuan (fullscreen).

3) Pengujian

Tahap ini bertujuan untuk menguji apakah semua fungsi dapat berjalan dengan baik. Selain itu, tahap ini juga bertujuan untuk menguji apakah eksekusi media pembelajaran modul interaktif sesuai dengan konsep yang telah ditentukan sebelumnya.

\section{4) Publishing}

Tahap publishing merupakan proses pentransferan flash document (.fla) menjadi file Adobe Flash Player. File tersebut dapat dipindahkan ke dalam Compact Disk (CD) atau flashdisk, sehingga dapat digunakan di komputer atau laptop yang lain.

b. Validasi Materi

Materi pembelajaran divalidasi oleh 1 (satu) orang ahli materi, yaitu Ibu Melti Roza Adry, SE, ME (Dosen Matematika Ekonomi di Program Studi Ekonomi Pembangunan Fakultas Ekonomi Universitas Negeri Padang). Instrumen penilaian berbentuk angket yang disusun menggunakan skala likert dengan 5 (lima) alternatif jawaban, yaitu Sangat Baik, Baik, Cukup, Tidak Baik, dan Sangat Tidak Baik. Instrumen penilaian ahli materi ini terdiri atas 20 (dua puluh) item pernyataan, yaitu 12 (dua belas) item pernyataan tentang aspek isi materi dan 8 (delapan) item pernyataan tentang aspek pembelajaran.

Materi pembelajaran ini divalidasi oleh Ibu Melti Roza Adry, SE, ME pada 08 Mei 2018. Adapun hasil penilaian ahli materi adalah sebagai berikut: 
Tabel 1. Hasil Penilaian Ahli Materi

\begin{tabular}{|c|c|c|}
\hline No. & Pernyataan & Skor \\
\hline \multicolumn{3}{|c|}{ Aspek Isi Materi } \\
\hline 1. & Kebenaran konsep dari materi yang disajikan & 4 \\
\hline 2. & Cakupan materi yang disajikan & 4 \\
\hline 3. & Kelengkapan materi yang disajikan & 3 \\
\hline 4. & Kejelasan materi yang disajikan & 3 \\
\hline 5. & Keruntutan materi yang disajikan & 3 \\
\hline 6. & Kebenaran contoh yang disajikan & 4 \\
\hline 7. & Kejelasan contoh yang disajikan & 4 \\
\hline 8. & Kebenaran konsep soal yang disajikan & 4 \\
\hline 9. & Cakupan soal yang disajikan & 3 \\
\hline 10. & Keruntutan soal yang disajikan & 4 \\
\hline 11. & Kejelasan soal yang disajikan & 3 \\
\hline 12. & Kebenaran kunci jawaban yang disajikan & 4 \\
\hline & Total Skor & 43 \\
\hline & Rata- Rata Skor & 3,58 \\
\hline & Kategori & Layak \\
\hline \multicolumn{3}{|c|}{ Aspek Pembelajaran } \\
\hline 13. & Kejelasan tujuan pembelajaran & 4 \\
\hline 14. & Kesesuaian materi dengan tujuan pembelajaran & 4 \\
\hline 15. & Kemenarikan materi yang disajikan & 4 \\
\hline 16. & Kemudahan dalam memahami materi yang disajikan & 4 \\
\hline 17. & $\begin{array}{l}\text { Meningkatkan motivasi belajar mahasiswa pada mata kuliah Matematika } \\
\text { Ekonomi }\end{array}$ & 3 \\
\hline 18. & Ketepatan pemilihan bahasa yang digunakan & 4 \\
\hline 19. & Pemberian latihan untuk pemahaman konsep & 3 \\
\hline 20. & Tingkat kesulitan soal yang disajikan & 3 \\
\hline & Total Skor & 32 \\
\hline & Rata- Rata Skor & 4,00 \\
\hline & Kategori & Layak \\
\hline
\end{tabular}

\section{Sumber: Pengolahan Data Primer, 2018}

Penilaian dari validator ini peneliti jadikan sebagai dasar dalam merevisi materi pembelajaran. Setelah peneliti melakukan revisi terhadap materi pembelajaran, maka pada 21 Mei 2018 peneliti menemui Ibu
Melti Roza Adry, SE, ME untuk menunjukkan revisi materi pembelajaran. Adapun hasil penilaian ahli materi setelah revisi adalah sebagai berikut:

Tabel 2. Hasil Penilaian Ahli Materi Setelah Revisi

\begin{tabular}{|c|c|c|}
\hline No. & Pernyataan & Skor \\
\hline \multicolumn{3}{|c|}{ Aspek Isi Materi } \\
\hline 1. & Kebenaran konsep dari materi yang disajikan & 5 \\
\hline 2. & Cakupan materi yang disajikan & 5 \\
\hline 3. & Kelengkapan materi yang disajikan & 5 \\
\hline 4. & Kejelasan materi yang disajikan & 5 \\
\hline 5. & Keruntutan materi yang disajikan & 5 \\
\hline 6. & Kebenaran contoh yang disajikan & 5 \\
\hline 7. & Kejelasan contoh yang disajikan & 5 \\
\hline 8. & Kebenaran konsep soal yang disajikan & 5 \\
\hline 9. & Cakupan soal yang disajikan & 5 \\
\hline 10. & Keruntutan soal yang disajikan & 5 \\
\hline 11. & Kejelasan soal yang disajikan & 5 \\
\hline 12. & Kebenaran kunci jawaban yang disajikan & 5 \\
\hline & Total Skor & 60 \\
\hline & Rata- Rata Skor & 5 \\
\hline & Kategori & Sangat Layak \\
\hline \multicolumn{3}{|c|}{ Aspek Pembelajaran } \\
\hline 13. & Kejelasan tujuan pembelajaran & 5 \\
\hline
\end{tabular}


14. Kesesuaian materi dengan tujuan pembelajaran 5

15. Kemenarikan materi yang disajikan 5

16. Kemudahan dalam memahami materi yang disajikan 5

17. Meningkatkan motivasi belajar mahasiswa pada mata kuliah Matematika 5

18. Ketepatan pemilihan bahasa yang digunakan 5

19. Pemberian latihan untuk pemahaman konsep 5

20. Tingkat kesulitan soal yang disajikan 4

Total Skor $\quad 39$

Kategori Sangat Layak

Sumber: Pengolahan Data Primer, 2018

c. Revisi Materi

Adapun komentar dan saran perbaikan yang diberikan oleh Ibu Melti Roza Adry,
SE, ME pada tanggal 08 Mei 2018 adalah sebagai berikut:

\section{Tabel 3. Komentar dan Saran Perbaikan Ahli Materi}

\begin{tabular}{cll}
\hline No. & \multicolumn{1}{c}{ Komentar / Saran Perbaikan } & Keputusan \\
\hline 1. & $\begin{array}{l}\text { Keterkaitan materi dengan konsep ekonomi perlu } \\
\text { ditambahkan dengan merujuk mikro dan makro ekonomi. }\end{array}$ & Sudah direvisi \\
2. & $\begin{array}{l}\text { Aplikasi dalam ekonomi diperjelas sesuai dengan konsep } \\
\text { mikro dan makro ekonomi. }\end{array}$ & Sudah direvisi \\
& $\begin{array}{l}\text { Kesesuaian soal dengan penjelasan matematis dan grafik. } \\
\text { 3. }\end{array}$ & $\begin{array}{l}\text { Sudah direvisi } \\
\text { Kedalaman materi dan aplikasi soal yang lebih variatif. }\end{array}$ \\
\hline
\end{tabular}

d. Validasi Media

Media pembelajaran divalidasi oleh 1 (satu) orang ahli media, yaitu Bapak Dr. Zulyadaini, M.Pd (Dosen Program Studi Pendidikan Matematika Fakultas Keguruan dan Ilmu Pendidikan Universitas Batanghari Jambi). Instrumen penilaian berbentuk angket yang disusun menggunakan skala likert dengan 5 (lima) alternatif jawaban, yaitu Sangat Baik, Baik, Cukup, Tidak Baik, dan
Sangat Tidak Baik. Instrumen penilaian ahli media ini terdiri atas 20 (dua puluh) item pernyataan, yaitu 14 (empat belas) item pernyataan tentang aspek tampilan dan penyajian serta 6 (enam) item pernyataan tentang aspek pemprograman.

Media pembelajaran ini divalidasi oleh Bapak Dr. Zulyadaini, M.Pd pada 25 Juni 2018. Adapun hasil penilaian ahli media adalah sebagai berikut:

Tabel 4. Hasil Penilaian Ahli Media

\begin{tabular}{|c|c|c|}
\hline No. & Pernyataan & Skor \\
\hline \multicolumn{3}{|c|}{ Aspek Tampilan dan Penyajian } \\
\hline 1. & Ketepatan penempatan teks dalam modul interaktif & 5 \\
\hline 2. & Ketepatan penempatan layout dalam modul interaktif & 5 \\
\hline 3. & Keruntutan layout dalam modul interaktif & 5 \\
\hline 4. & Ketepatan penempatan gambar dalam modul interaktif & 4 \\
\hline 5. & Ketepatan penggunaan gambar dalam modul interaktif & 4 \\
\hline 6. & Perpaduan warna teks dan background dalam modul interaktif & 4 \\
\hline 7. & Ketepatan pemilihan warna media yang digunakan & 4 \\
\hline 8. & Ketepatan pemilihan font yang digunakan dalam menyajikan materi & 4 \\
\hline 9. & $\begin{array}{l}\text { Ketepatan pemilihan ukuran font yang digunakan dalam menyajikan } \\
\text { materi }\end{array}$ & 5 \\
\hline 10. & Ketepatan pemilihan jarak dan spasi teks dalam modul interaktif & 5 \\
\hline 11. & Keterbacaan teks yang disajikan dalam modul interaktif & 5 \\
\hline 12. & Keruntutan penyajian materi dalam modul interaktif & 5 \\
\hline 13. & Kejelasan musik yang digunakan dalam modul interakif & 5 \\
\hline \multirow[t]{4}{*}{14.} & Ketepatan musik yang digunakan dalam modul interaktif & 5 \\
\hline & Total Skor & 65 \\
\hline & Rata-rata Skor & 4,64 \\
\hline & Kategori & Sangat Layak \\
\hline
\end{tabular}




\section{Aspek Pemprograman}

$\begin{array}{llc}15 . & \text { Keefektifan modul interaktif sebagai media pembelajaran } & 5 \\ 16 . & \text { Kemudahan dalam menggunakan modul interaktif } & 5 \\ 17 . & \text { Kesederhanaan dalam pengoperasian modul interaktif } & 5 \\ 18 . & \text { Kemudahan dalam menginstalasi modul interaktif } & 4 \\ 19 . & \text { Kejelasan petunjuk penggunaan modul interaktif } & 5 \\ 20 . & \text { Kreativitas dalam mengembangkan modul interaktif } & 5 \\ & \text { Total Skor } & \mathbf{2 9} \\ & \text { Rata-rata Skor } & \mathbf{4 , 8 3} \\ & \text { Kategori } & \text { Sangat Layak }\end{array}$

\section{Sumber: Pengolahan Data Primer, 2018}

Penilaian dari validator ini peneliti jadikan sebagai dasar dalam merevisi media pembelajaran. Setelah peneliti melakukan revisi terhadap media pembelajaran, maka pada 27 Juni 2018 peneliti menemui Bapak
Dr. Zulyadaini, M.Pd untuk menunjukkan media pembelajaran yang telah peneliti revisi. Adapun hasil penilaian ahli media setelah revisi adalah sebagai berikut:

\section{Tabel 5. Hasil Penilaian Ahli Media Setelah Revisi}

\begin{tabular}{|c|c|c|}
\hline No. & Pernyataan & Skor \\
\hline \multicolumn{3}{|c|}{ Aspek Tampilan dan Penyajian } \\
\hline 1. & Ketepatan penempatan teks dalam modul interaktif & 5 \\
\hline 2. & Ketepatan penempatan layout dalam modul interaktif & 5 \\
\hline 3. & Keruntutan layout dalam modul interaktif & 5 \\
\hline 4. & Ketepatan penempatan gambar dalam modul interaktif & 4 \\
\hline 5. & Ketepatan penggunaan gambar dalam modul interaktif & 4 \\
\hline 6. & Perpaduan warna teks dan background dalam modul interaktif & 5 \\
\hline 7. & Ketepatan pemilihan warna media yang digunakan & 5 \\
\hline 8. & Ketepatan pemilihan font yang digunakan dalam menyajikan materi & 5 \\
\hline 9. & $\begin{array}{l}\text { Ketepatan pemilihan ukuran font yang digunakan dalam menyajikan } \\
\text { materi }\end{array}$ & 5 \\
\hline 10. & Ketepatan pemilihan jarak dan spasi teks dalam modul interaktif & 5 \\
\hline 11. & Keterbacaan teks yang disajikan dalam modul interaktif & 5 \\
\hline 12. & Keruntutan penyajian materi dalam modul interaktif & 5 \\
\hline 13. & Kejelasan musik yang digunakan dalam modul interakif & 5 \\
\hline 14. & Ketepatan musik yang digunakan dalam modul interaktif & 5 \\
\hline & Total Skor & 68 \\
\hline & Rata-rata Skor & 4,86 \\
\hline & Kategori & Sangat Layak \\
\hline \multicolumn{3}{|c|}{ Aspek Pemprograman } \\
\hline 15. & Keefektifan modul interaktif sebagai media pembelajaran & 5 \\
\hline 16. & Kemudahan dalam menggunakan modul interaktif & 5 \\
\hline 17. & Kesederhanaan dalam pengoperasian modul interaktif & 5 \\
\hline 18. & Kemudahan dalam menginstalasi modul interaktif & 4 \\
\hline 19. & Kejelasan petunjuk penggunaan modul interaktif & 5 \\
\hline 20. & Kreativitas dalam mengembangkan modul interaktif & 5 \\
\hline & Total Skor & 29 \\
\hline & Rata-rata Skor & $\mathbf{4 , 8 3}$ \\
\hline & Kategori & Sangat Layak \\
\hline
\end{tabular}

Sumber: Pengolahan Data Primer, 2018

e. Revisi Media

Adapun komentar dan saran perbaikan yang diberikan oleh Bapak Dr. Zulyadaini,
M.Pd pada tanggal 25 Juni 2018 adalah sebagai berikut: 
Tabel 6. Komentar dan Saran Perbaikan Ahli Media

\begin{tabular}{clc}
\hline No. & \multicolumn{1}{c}{ Komentar / Saran Perbaikan } & Keputusan \\
\hline 1. & $\begin{array}{l}\text { Sebaiknya kata-kata kunci materi dibedakan font dan } \\
\text { warnanya dari teks yang lain. }\end{array}$ & Sudah direvisi \\
2. & $\begin{array}{l}\text { Warna background pada beranda diperbaiki dengan } \\
\text { pemilihan warna yang lebih menarik. }\end{array}$ & Sudah direvisi \\
\hline
\end{tabular}

\section{Implementasi (Implement)}

Setelah materi dan media pembelajaran direvisi sesuai dengan komentar dan saran dari validator, maka penelitian ini peneliti lanjutkan pada tahap implementasi, yang terdiri atas langkah-langkah sebagai berikut:

\section{a. One to One}

Tahap One to One peneliti laksanakan pada 02 Juli 2018. Pada tahap ini, media pembelajaran modul interaktif peneliti ujicobakan kepada 3 (tiga) orang mahasiswa. Sebelum pelaksanaan ujicoba, peneliti meminta mahasiswa untuk menginstall software Adobe Flash CS 6 dan mengcopy modul interaktif ke dalam laptop masingmasing peserta One to One. Selanjutnya, peneliti memandu mahasiswa dalam mengoperasikan media pembelajaran modul interaktif di depan kelas. Pada akhir pertemuan, peneliti memberikan instrumen penilaian yang berkaitan dengan penilaian mahasiswa tentang materi dan media pembelajaran yang telah dioperasikan. Instrumen penilaian ini berbentuk angket yang disusun menggunakan skala likert dengan 5 (lima) alternatif jawaban, yaitu Sangat Baik, Baik, Cukup, Tidak Baik, dan Sangat Tidak Baik. Instrumen penilaian mahasiswa ini terdiri atas 25 (dua puluh lima) item pernyataan, yaitu 7 (tujuh) item pernyataan tentang aspek isi materi, 5 (lima) item pernyataan tentang aspek pembelajaran, 9 (sembilan) item pernyataan tentang aspek penyajian dan tampilan, serta 4 (empat) item pernyataan tentang aspek pemprograman. Rekapitulasi penilaian mahasiswa peserta One to One ini tergambar pada tabel di bawah ini:

Tabel 7. Rekapitulasi Hasil Penilaian Mahasiswa Peserta One to One

\begin{tabular}{clcc}
\hline No. & & Aspek & Rerata \\
\hline 1. & Isi Materi & 4,33 \\
2. & Pembelajaran & 4,13 \\
3. & Penyajian dan Tampilan & & 4,07 \\
4. & Pemprograman & 4,17 \\
Rerata Seluruh Aspek & $\mathbf{4 , 1 7}$ \\
Kategori & & Layak \\
\hline
\end{tabular}

Sumber: Pengolahan Data Primer, 2018

Berdasarkan kriteria konversi diketahui bahwa (1) aspek isi materi memperoleh rerata 4,33, sehingga berada pada kategori sangat layak, (2) aspek pembelajaran memperoleh rerata 4,13, sehingga berada pada kategori layak, (3) aspek penyajian dan tampilan memperoleh rerata 4,07 , sehingga berada pada kategori layak, dan (4) aspek pemprograman memperoleh rerata 4,17, sehingga berada pada kategori layak. Dengan demikian, secara keseluruhan penilaian mahasiswa peserta One to One tentang media pembelajaran berada pada kategori layak.

b. Small Group

Tahap Small Group peneliti laksanakan pada 09 Juli 2018. Pada tahap ini, media pembelajaran modul interaktif peneliti ujicobakan kepada 7 (tujuh) orang mahasiswa. Sebelum pelaksanaan ujicoba, peneliti meminta mahasiswa untuk menginstall software Adobe Flash CS 6 dan mengcopy modul interaktif ke dalam laptop masing-masing peserta Small Group. Selanjutnya, peneliti memandu mahasiswa dalam mengoperasikan media pembelajaran modul interaktif di depan kelas. Pada akhir pertemuan, peneliti memberikan instrumen penilaian yang berkaitan dengan penilaian mahasiswa tentang materi dan media pembelajaran yang telah dioperasikan. Instrumen penilaian ini berbentuk angket yang disusun menggunakan skala likert dengan 5 (lima) alternatif jawaban, yaitu Sangat Baik, Baik, Cukup, Tidak Baik, dan Sangat Tidak Baik. Instrumen penilaian mahasiswa ini terdiri atas 25 (dua puluh lima) item pernyataan, yaitu 7 (tujuh) item pernyataan tentang aspek isi materi, 5 (lima) 
item pernyataan tentang aspek pembelajaran, 9 (sembilan) item pernyataan tentang aspek penyajian dan tampilan, serta 4 (empat) item pernyataan tentang aspek pemprograman.
Rekapitulasi penilaian mahasiswa peserta Small Group ini tergambar pada tabel di bawah ini:

\section{Tabel 8. Rekapitulasi Hasil Penilaian Mahasiswa Peserta Small Group}

No.

1. Isi Materi

2. Pembelajaran

3. Penyajian dan Tampilan

4. Pemprograman

Rerata Seluruh Aspek

Kategori

Sumber: Pengolahan Data Primer, 2018

Berdasarkan kriteria konversi diketahui bahwa (1) aspek isi materi memperoleh rerata 4,65 , sehingga berada pada kategori sangat layak, (2) aspek pembelajaran memperoleh rerata 4,49 , sehingga berada pada kategori sangat layak, (3) aspek penyajian dan tampilan memperoleh rerata 4,52, sehingga berada pada kategori sangat layak, dan (4) aspek pemprograman memperoleh rerata 4,61, sehingga berada pada kategori sangat layak. Dengan demikian, secara keseluruhan penilaian mahasiswa peserta Small Group tentang media pembelajaran berada pada kategori sangat layak.

c. Field Test

Tahap Field Test peneliti laksanakan pada 28 Juli 2018. Pada tahap ini, media pembelajaran modul interaktif peneliti terapkan kepada 20 (dua puluh) orang mahasiswa. Peneliti mengoperasikan media pembelajaran modul interaktif di depan kelas
Rerata

4,65

4,49

4,52

4,61

4,57

Sangat Layak

dengan menggunakan LCD dan speaker yang tersedia. Pada akhir pertemuan, peneliti memberikan instrumen penilaian yang berkaitan dengan penilaian mahasiswa tentang materi dan media pembelajaran yang telah dioperasikan. Instrumen penilaian ini berbentuk angket yang disusun menggunakan skala likert dengan 5 (lima) alternatif jawaban, yaitu Sangat Baik, Baik, Cukup, Tidak Baik, dan Sangat Tidak Baik. Instrumen penilaian mahasiswa ini terdiri atas 25 (dua puluh lima) item pernyataan, yaitu 7 (tujuh) item pernyataan tentang aspek isi materi, 5 (lima) item pernyataan tentang aspek pembelajaran, 9 (sembilan) item pernyataan tentang aspek penyajian dan tampilan, serta 4 (empat) item pernyataan tentang aspek pemprograman. Rekapitulasi penilaian mahasiswa peserta Field Test ini tergambar pada tabel di bawah ini:

Tabel 9. Rekapitulasi Hasil Penilaian Mahasiswa Peserta Field Test

\begin{tabular}{clcc}
\hline No. & Aspek & Rerata \\
\hline 1. & Isi Materi & & 4,28 \\
2. & Pembelajaran & & 4,22 \\
3. & Penyajian dan Tampilan & & 4,21 \\
4. & Pemprograman & 4,33 \\
Rerata Seluruh Aspek & & $\mathbf{4 , 2 5}$ \\
Kategori & & Sangat Layak \\
\hline
\end{tabular}

Sumber: Pengolahan Data Primer, 2018

Berdasarkan kriteria konversi diketahui bahwa (1) aspek isi materi memperoleh rerata 4,28 , sehingga berada pada kategori sangat layak, (2) aspek pembelajaran memperoleh rerata 4,22, sehingga berada pada kategori sangat layak, (3) aspek penyajian dan tampilan memperoleh rerata 4,21 , sehingga berada pada kategori sangat layak, dan (4) aspek pemprograman memperoleh rerata 4,33, sehingga berada pada kategori sangat layak. Dengan demikian, secara keseluruhan penilaian mahasiswa peserta Field Test tentang media pembelajaran berada pada kategori sangat layak.

Pada tahap Field Test ini, peneliti juga membagikan 20 (dua puluh) CD yang berisi media pembelajaran dan telah di burning, sehingga mahasiswa bisa menggunakannya 
sebagai sumber belajar di manapun dan kapan pun.

\section{Evaluasi (Evaluate)}

Pada tahap evaluasi ini, langkah-langkah yang peneliti lakukan adalah sebagai berikut:

1. Menganalisis penilaian ahli materi dan ahli media

Pada tahap ini, peneliti menganalisis penilaian dari ahli materi tentang materi pembelajaran yang disusun serta penilaian dari ahli media tentang media pembelajaran yang dikembangkan.

2. Menganalisis penilaian mahasiswa

Pada tahap ini, peneliti menganalisis penilaian mahasiswa tentang media pembelajaran yang dikembangkan.

3. Produk akhir

Setelah dilakukan proses validasi dan revisi, maka diperoleh produk akhir berupa media pembelajaran modul interaktif dengan software Adobe Flash pada mata kuliah Matematika Ekonomi.
Kelayakan Media Pembelajaran Modul Interaktif dengan Software Adobe Flash pada Mata Kuliah Matematika Ekonomi di Universitas Batanghari Jambi Berdasarkan Penilaian Ahli Materi dan Ahli Media.

\section{Ahli Materi}

Materi pembelajaran yang telah disusun divalidasi oleh 1 (satu) orang dosen Matematika Ekonomi di Program Studi Ekonomi Pembangunan Fakultas Ekonomi Universitas Negeri Padang, yaitu Ibu Melti Roza Adry, SE, MM. Validator memberikan penilaian terhadap materi pembelajaran yang peneliti susun dengan mengisi instrumen penilaian yang telah disediakan, yang terdiri dari 20 (dua puluh) item pernyataan. Adapun aspek yang dinilai oleh validator adalah aspek isi materi dan aspek pembelajaran.

Rekapitulasi penilaian validator ini tergambar pada tabel di bawah ini:

Tabel 10. Rekapitulasi Hasil Penilaian Ahli Materi

\begin{tabular}{ccccc}
\hline No. & & Aspek & Rerata & Kategori \\
\hline 1. & Isi Materi & 3,58 & Layak \\
2. & Pembelajaran & 4,00 & Layak \\
Rerata Seluruh Aspek & & $\mathbf{3 , 7 9}$ & Layak \\
\hline
\end{tabular}

Sumber: Pengolahan Data Primer, 2018

Setelah peneliti merevisi materi pembelajaran sesuai dengan komentar dan saran dari validator, maka peneliti menemui kembali validator guna menunjukkan hasil revisi yang peneliti susun. Selanjutnya, peneliti meminta validator untuk mengisi kembali instrumen penilaian yang disediakan. Rekapitulasi penilaian validator setelah revisi tergambar pada tabel di bawah ini:

Tabel 11. Rekapitulasi Hasil Penilaian Ahli Materi Setelah Revisi

\begin{tabular}{ccccc}
\hline No. & & Aspek & Rerata & Kategori \\
\hline 1. & Isi Materi & & 5,00 & Sangat Layak \\
2. & Pembelajaran & 4,88 & Sangat Layak \\
Rerata & Seluruh Aspek & $\mathbf{4 , 9 4}$ & Sangat Layak \\
\hline
\end{tabular}

Sumber: Pengolahan Data Primer, 2018

Berdasarkan kriteria konversi diketahui bahwa (1) aspek isi materi memperoleh rerata 5,00 , sehingga berada pada kategori sangat layak, dan (2) aspek pembelajaran memperoleh rerata 4,88, sehingga berada pada kategori sangat layak. Dengan demikian, secara keseluruhan penilaian ahli materi setelah revisi berada pada kategori sangat layak.

Ahli Media
Media pembelajaran yang telah disusun divalidasi oleh 1 (satu) orang dosen Program Studi Pendididkan Matematika Fakultas Keguruan dan Ilmu Pendidikan Universitas Batanghari Jambi, yaitu Bapak Dr. Zulyadaini, M.Pd. Validator memberikan penilaian terhadap media pembelajaran yang peneliti susun dengan mengisi instrumen penilaian yang telah disediakan, yang terdiri dari 20 (dua puluh) item pernyataan. Adapun aspek yang dinilai oleh 
validator adalah aspek tampilan dan penyajian serta aspek pemprograman.
Rekapitulasi penilaian validator ini tergambar pada tabel di bawah ini:

Tabel 12. Rekapitulasi Hasil Penilaian Ahli Media

\begin{tabular}{cccc}
\hline No. & \multicolumn{1}{c}{ Aspek } & Rerata & Kategori \\
\hline 1. & Tampilan dan Penyajian & 4,64 & Sangat Layak \\
2. & Pemprograman & 4,83 & Sangat Layak \\
Rerata Seluruh Aspek & $\mathbf{4 , 7 4}$ & Sangat Layak \\
\hline
\end{tabular}

Sumber: Pengolahan Data Primer, 2018

Setelah peneliti merevisi media pembelajaran sesuai dengan komentar dan saran dari validator, maka peneliti menemui kembali validator guna menunjukkan hasil revisi yang peneliti susun. Selanjutnya, peneliti meminta

validator untuk mengisi kembali instrumen penilaian yang disediakan. Rekapitulasi penilaian validator setelah revisi tergambar pada tabel di bawah ini:

Tabel 13. Rekapitulasi Hasil Penilaian Ahli Media Setelah Revisi

\begin{tabular}{cccc}
\hline No. & \multicolumn{1}{c}{ Aspek } & Rerata & Kategori \\
\hline 1. & Tampilan dan Penyajian & 4,86 & Sangat Layak \\
2. & Pemprograman & 4,83 & Sangat Layak \\
Rerata Seluruh Aspek & $\mathbf{4 , 8 5}$ & Sangat Layak \\
\hline
\end{tabular}

Sumber: Pengolahan Data Primer, 2018

Berdasarkan kriteria konversi diketahui bahwa (1) aspek tampilan dan penyajian memperoleh rerata 4,86 , sehingga berada pada kategori sangat layak, dan (2) aspek pemprograman memperoleh rerata 4,83, sehingga berada pada kategori sangat layak. Dengan demikian, secara keseluruhan penilaian ahli media setelah revisi berada pada kategori sangat layak.

Kelayakan Media Pembelajaran Modul Interaktif dengan Software Adobe Flash pada Mata Kuliah Matematika Ekonomi di

\section{Universitas Batanghari Jambi berdasarkan Penilaian Mahasiswa.}

Kelayakan media pembelajaran berdasarkan penilaian mahasiswa peneliti peroleh dari hasil tahap Field Test yang telah peneliti laksanakan pada tanggal 28 Juli 2018 dengan subjek 20 (dua puluh) orang mahasiswa Program Studi Pendidikan Ekonomi Fakultas Keguruan dan Ilmu Pendidikan Universitas Batanghari Jambi. Rekapitulasi penilaian mahasiswa peserta Field Test ini tergambar pada tabel di bawah ini:

Tabel 14. Rekapitulasi Hasil Penilaian Mahasiswa Peserta Field Test

No.

1. Isi Materi

2. Pembelajaran

3. Penyajian dan Tampilan

4. Pemprograman

Rerata Seluruh Aspek

Kategori

Sumber: Pengolahan Data Primer, 2018

Berdasarkan kriteria konversi diketahui bahwa (1) aspek isi materi memperoleh rerata 4,28, sehingga berada pada kategori sangat layak, (2) aspek pembelajaran memperoleh rerata 4,22 , sehingga berada pada kategori sangat layak, (3) aspek penyajian dan tampilan memperoleh rerata 4,21 , sehingga berada pada kategori sangat layak, dan (4) aspek pemprograman memperoleh rerata 4,33, sehingga berada pada kategori sangat layak.
Dengan demikian, secara keseluruhan penilaian mahasiswa peserta Field Test tentang media pembelajaran berada pada kategori sangat layak.

\section{PEMBAHASAN}

Hasil penelitian yang peneliti temukan ini didukung oleh hasil penelitian Rahmaibu (2016: 9) yang menemukan bahwa evaluasi oleh ahli materi, produk memperoleh kelayakan dengan persentase sebesar $90 \%$ yang berarti sangat layak 
dan oleh ahli media mendapat skor kelayakan dengan persentase $80 \%$ yang berarti layak. Berdasarkan hasil ekperimen di kelas sampel, rata-rata pre-test (sebelum menggunakan media) adalah 71,75, sedangkan rata-rata post-test (sesudah menggunakan media) adalah 83. Peningkatan hasil belajar tersebut membuktikan bahwa terdapat perbedaan yang signifikan antara hasil belajar PKn sebelum dan sesudah menggunakan media pembelajaran berbasis multimedia dengan menggunakan Adobe Flash. Selanjutnya, hasil penelitian ini juga diperkuat oleh penelitian Yusuf (2015: 68) yang menemukan bahwa tingkat pemahaman materi mahasiswa setelah mempelajari materi dalam media pembelajaran tergolong baik, yaitu terdapat $16,95 \%$ mahasiswa yang memiliki tingkat pemahaman materi yang sangat baik, $64,41 \%$ memiliki tingkat pemahaman materi dalam kategori baik, dan hanya $18,64 \%$ yang memiliki tingkat pemahaman materi dalam kategori cukup. Sedangkan, tingkat motivasi mahasiswa setelah mengikuti pembelajaran dengan menggunakan media hasil pengembangan menunjukkan bahwa terdapat $17,54 \%$ mahasiswa yang memiliki motivasi dalam kategori sangat tinggi, 77,19\% mahasiswa memiliki motivasi dalam kategori tinggi, dan hanya $5,26 \%$ mahasiswa yang memiliki motivasi dalam kategori sedang.

\section{SIMPULAN}

Berdasarkan hasil penelitian yang diperoleh, maka dapat diambil kesimpulan sebagai berikut:

1. Proses pengembangan media pembelajaran modul interaktif dengan software Adobe Flash pada mata kuliah Matematika Ekonomi di Universitas Batanghari Jambi merujuk pada model pengembangan ADDIE yang terdiri dari 5 (lima) tahapan, yaitu Analisis (Analysis), Desain (Design), Pengembangan (Develop), Implementasi (Implement), dan Evaluasi (Evaluate).

2. Kelayakan media pembelajaran modul interaktif dengan software Adobe Flash pada mata kuliah Matematika Ekonomi di Universitas Batanghari Jambi berdasarkan penilaian ahli materi memperoleh rerata seluruh aspek, yaitu 4,94, sehingga materi pembelajaran sangat layak digunakan pada proses pembelajaran Matematika Ekonomi. Selanjutnya, berdasarkan penilaian ahli media memperoleh rerata seluruh aspek, yaitu 4,85 , sehingga media pembelajaran sangat layak digunakan pada proses pembelajaran Matematika Ekonomi.

3. Kelayakan media pembelajaran modul interaktif dengan software Adobe Flash pada mata kuliah Matematika Ekonomi di Universitas Batanghari Jambi berdasarkan penilaian mahasiswa memperoleh rerata seluruh aspek, yaitu 4, 25, sehingga media pembelajaran sangat layak digunakan pada proses pembelajaran Matematika Ekonomi.

\section{DAFTAR PUSTAKA}

Gafur, Abdul. 2012. Desain Pembelajaran: Konsep, Model, dan Aplikasinya dalam Perencanaan Pelaksanaan Pembelajaran. Yogyakarta: Ombak.

Hamdani. 2011. Strategi Belajar Mengajar. Bandung: CV. Pustaka Setia.

Rahmaibu, Farida Hasan, Farid Ahmadi, dan Fitria Dwi Prasetyaningsih. 2016. "Pengembangan Media Pembelajaran Menggunakan Adobe Flash untuk Meningkatkan Hasil Belajar PKn". Jurnal Kreatif: Universitas Negeri Semarang, Vol. 7, No. 1, 1-10.

Sadiman, Arief S. 2011. Media Pendidikan: Pengertian, Pengembangan, dan Pemanfaatannya. Jakarta: PT. Grafindo Persada.

Sugiyono. 2011. Metode Penelitian Kuantitatif, Kualitatif, dan $R \& D$. Bandung: Alfabeta.

Yusuf, A. Momang. 2015. "Pengembangan Media Pembelajaran Berbasis Adobe Flash untuk Mata Kuliah Fisika Modern Materi Radiasi Benda Hitam". Jurnal Sains dan Pendidikan Fisika: Universitas Negeri Makasar, Vol. 11, No. 1, 57-71. 